\title{
Accelerated Nodulosis in a Patient With Rheumatoid Arthritis
}

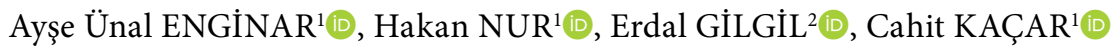 \\ ${ }^{1}$ Department of Physical Medicine and Rehabilitation, Akdeniz University Faculty Of Medicine, Antalya, Turkey \\ ${ }^{2}$ Special Rheumatologist, Antalya, Turkey
}

\begin{abstract}
In patients with rheumatoid arthritis (RA), subcutaneous nodules are the most frequently seen extra-articular findings that are seen in areas of extensor pressure. In this article, we present the case of a RA patient with accelerated nodulosis that started with the use of methotrexate and exacerbated with etanercept and leflunomide treatment.

Keywords: Accelerated nodulosis, anti-tumor necrosis factor drugs, methotrexate, rheumatoid arthritis.
\end{abstract}

Rheumatoid arthritis (RA) is a progressive, systemic inflammatory disease with articular and extra-articular involvement. The skin is the most common location of extra-articular involvement and subcutaneous nodules are seen in $25 \%$ of RA patients. These are granulomatous nodules below the skin, often seen in extensor areas under external pressure and they may also be seen in the elbow ${ }^{1}$ They were also reported in the lungs, the heart and the meniscus. ${ }^{2}$ Compared to rheumatoid nodules, accelerated nodules have a more rapid onset and growth, are smaller and follow a different distribution (hand, foot, and ear). ${ }^{3}$ Accelerated nodules can be seen with methotrexate (MTX), anti-tumor necrosis factor (anti-TNF) drugs and occasionally with leflunomide and azathioprine treatment., ${ }^{4,5}$ The case presented here is a patient with RA who developed accelerated nodulosis with the use of MTX that exacerbated with the later use of etanercept and leflunomide.

\section{CASE REPORT}

A 42-year-old female patient, who was followed-up for 23 years with a diagnosis of seropositive RA, was on MTX treatment. After five-year use of MTX, she presented with newly developed nodules on the hands and feet. Because of increased nodules and clinical activity, MTX was switched to sulfasalazine. However, it failed to improve the nodules. Owing to this and increased disease activity, treatment was changed to etanercept. After five-year use, etanercept treatment was terminated because of the increased number and size of the nodules in the previous year. The physical examination revealed deformities of the hands and feet typical for RA. There were multiple nodules bilaterally on the extensor surfaces of the hands and feet, on the lateral side of the feet and the palmar surfaces of the hands, which were painless and of moderate hardness. They varied in diameter

Received: May 18, 2018 Accepted: September 14, 2018 Published online: November 30, 2018

Correspondence: Ayşe Ünal Enginar, MD. Akdeniz Üniversitesi Tıp Fakültesi Fiziksel Tıp ve Rehabilitasyon Anabilim Dalı, 07070 Konyaaltı, Antalya, Turkey. Tel: +90 532 - 7239988 e-mail: ftrdrayseenginar@gmail.com 
ranging from 0.5 to $1.5 \mathrm{~cm}$ (Figure 1a, b). Disease activity score in 28 joints was 1.6 and results of laboratory studies were as follows: erythrocyte sedimentation rate: $39 \mathrm{~mm} /$ hour, C-reactive protein: $0.34 \mathrm{mg} / \mathrm{dL}$, antinuclear antibody titre: 1/320, rheumatoid factor (RF): 588 IU and anticyclic citrullinated peptide: 125 IU. An excision biopsy of one of the nodules was performed and found consistent with rheumatoid nodules (Figure 2). No pulmonary nodules were detected on computed tomography of the chest. After one year of withdrawal from etanercept, colchicine and leflunomide were started (Figure 3). After fourmonth use of leflunomide, the number of nodules increased even more, thereafter leflunomide
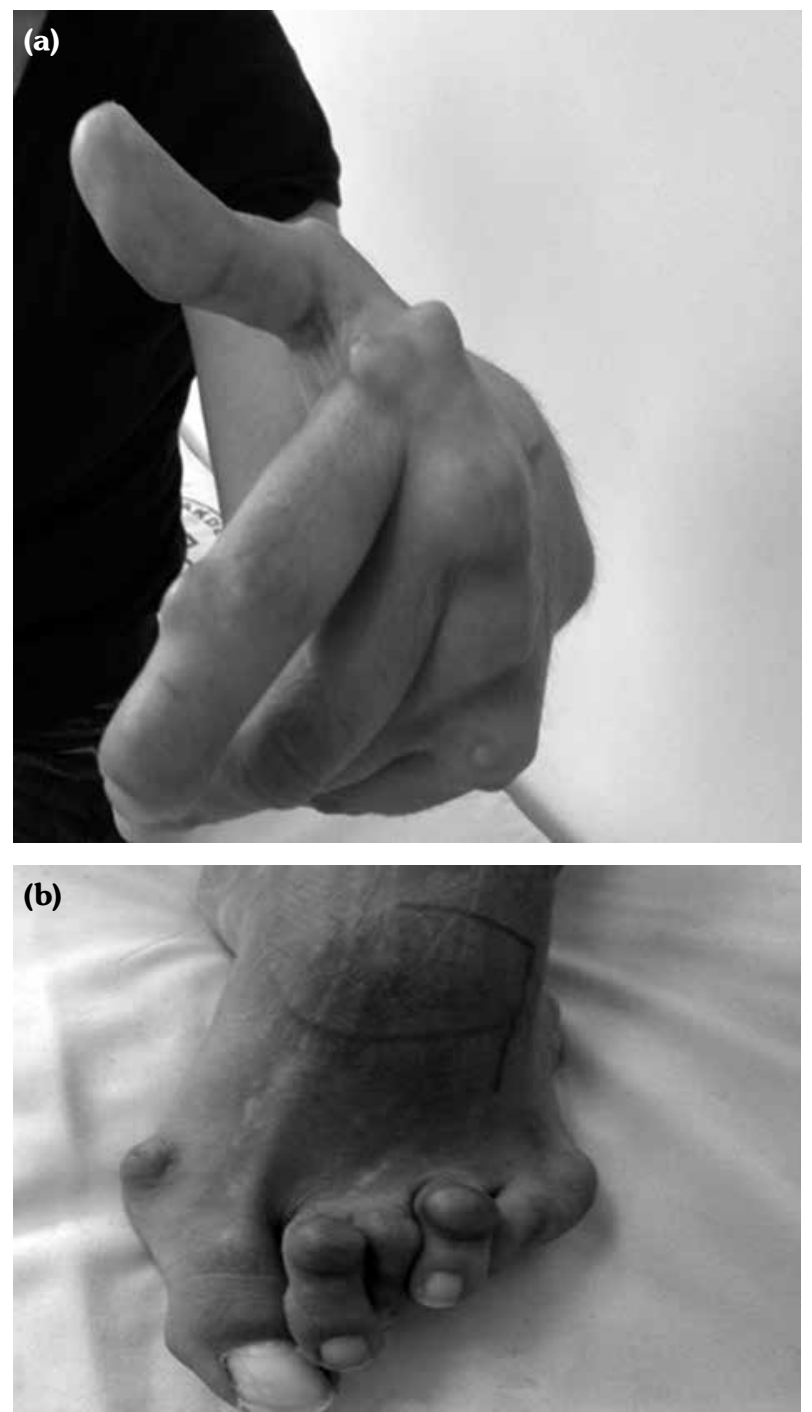

Figure 1. Nodulosis after etanercept. (a) hand, (b) foot was terminated and colchicine was continued (Figure 4). Although there was minor decrease with the use of colchicine in the number and size of the rheumatoid nodules on the extensor surface of the elbows, the number and size of the nodules on the hands and feet did not change.

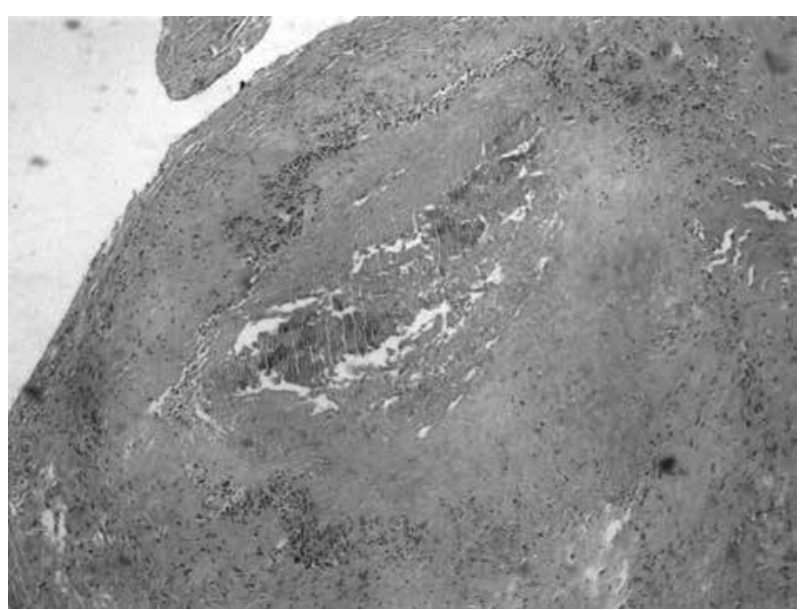

Figure 2. Biopsy in rheumatoid nodule (H-E×50).

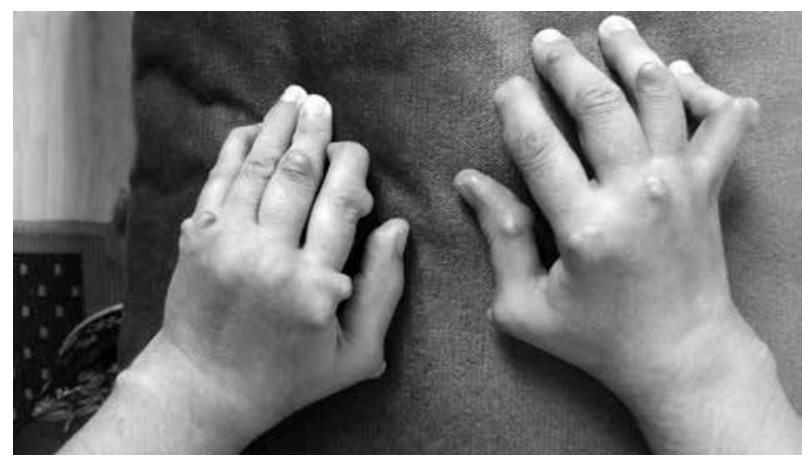

Figure 3. Nodulosis before leflunomide.

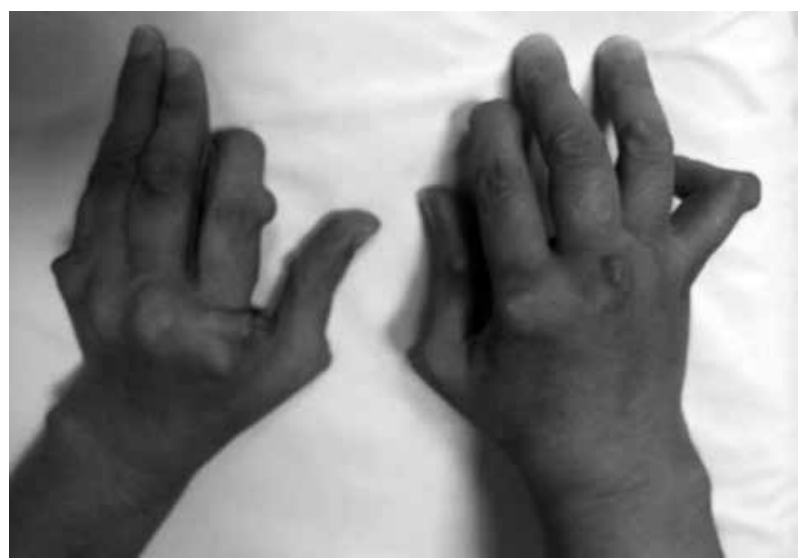

Figure 4. Nodulosis after termination of drugs. 
She was recommended to stop smoking and start rituximab; however, she did not approve the use of rituximab. Colchicine was stopped because of inefficacy and hydroxychloroquine was commenced. After follow-up of one year, she was not smoking anymore and was still on hydroxychloroquine. There were no newly formed nodules while there was no improvement in the previously formed nodules. A written informed consent was obtained from the patient.

\section{DISCUSSION}

Accelerated nodulosis was first described by Kremer and Lee in 1986 as increased number of nodules in three patients with long-term use of MTX. ${ }^{6}$ Since that time, several reports were published indicating that accelerated nodulosis was seen at rates of $8-11 \%$ in patients with RA taking MTX. ${ }^{4}$ Subcutaneous nodules may develop at a mean of three years after the start of MTX treatment. ${ }^{7}$ HLA-DRB1*0401 and RF positivity are related to MTX-induced accelerated nodulosis. ${ }^{3,8}$ There have been occasional reports of accelerated nodulosis associated with other disease modifying antirheumatic drugs other than MTX, such as leflunomide, azathioprine and antiTNF drugs, particularly etanercept. ${ }^{2,4,5}$ Newly emerged rheumatoid nodules mainly affect the hands, particularly the metacarpophalangeal and proximal interphalangeal joints. While MTXinduced accelerated nodulosis affects the hands at a rate of $88 \%$, non-accelerated nodulosis affects the hands at a rate of $34 \% .3,8,9$ Compared to classic rheumatoid nodules, accelerated nodules have more rapid onset and growth, are smaller and follow a different distribution (hand, foot, and ear). ${ }^{3}$ Accelerated nodules generally develop while there is low disease activity. Histopathologically, they are not different from rheumatoid nodules. They develop in three zones; internally mononuclear cells surrounding fibrinoid necrosis while externally there is granulomatous inflammation. ${ }^{6,10}$ The pathogenesis of drug-related nodulosis is not clear. Increased giant cell formation with A1 receptor stimulation and adenosine production stimulated from the monocytes by MTX could be effective in the pathogenesis and it is theorized that drugs which inhibit adenosine A1 receptor could be useful in MTX-induced accelerated nodulosis. ${ }^{11}$ The rheumatoid synovial membrane and rheumatoid nodules are histologically similar. Still, there are some differences. Unlike in the synovium, there are no B cells, plasma cells or organized lymphoid structures in rheumatoid nodules. In addition, E-selectin expression is higher in the blood vessels of rheumatoid nodules than in the synovium. Wikaningrum et al. ${ }^{12}$ determined that interleukin-1 beta (IL-1 $\beta$ ) was elevated in rheumatoid nodules and not in the synovium. Furthermore, the TNF-alpha $(\alpha)$ level was found to be high in the synovium and low in rheumatoid nodules. Cunnane et al. ${ }^{2}$ reported three cases of seropositive arthritis who developed nail bed infarcts and an increased number of nodules two-three months after starting etanercept treatment. It was thought that vasculitis, treatment-related cell death and increased chemotaxis could be responsible in the formation of nodules. Mackley et al. ${ }^{13}$ reported a seropositive RA patient who developed nodules on the hands one year after starting infliximab treatment. There is no proven treatment for accelerated rheumatoid nodulosis; therefore, it is wise to stop the offending drug. Various drugs have been attempted for the treatment of accelerated nodulosis, ${ }^{14}$ most commonly hydroxychloroquine, colchicine, D-penicillamine, and sulfasalazine. ${ }^{15-18}$ Cases of pulmonary nodules were reported that improved with tocilizumab and rituximab. ${ }^{19,20}$ Several cases of severe subcutaneous nodulosis treated with rituximab were also reported. ${ }^{21}$ In our patient, nodulosis started with the use of MTX first and even increased with further use of etanercept and leflunomide. Contrary to the reports in the literature, after withdrawal from drugs, neither the size nor the number of nodules decreased in our patient. Use of colchicine had a subtle effect and hydroxychloroquine had no effect. The development of nodulosis in our patient during a period of low disease activity was consistent with the literature. The patient being seropositive and having a history of smoking were risk factors for nodulosis, particularly for MTXinduced accelerated nodulosis. HLA-DRB1*0401 positivity was not evaluated in our patient as this evaluation is not available in routine practice at our hospital.

As TNF- $\alpha$ level is low in nodules, rituximab and other options might be considered in treatment rather than prioritizing anti-TNF drugs in those with accelerating nodulosis. Furthermore, as IL-1 $\beta$ 
is high in nodules, treatment with IL- $1 \beta$ inhibitors could be suggested as an option; however, further studies are needed to assess the efficacy of those. With a better understanding of the pathogenesis of accelerated nodulosis, new treatment options may emerge in the future. Otherwise, this clinical picture which may occur during the disease process of RA patients will continue to cause cosmetic concerns and further loss of function in such patients.

\section{Declaration of conflicting interests}

The authors declared no conflicts of interest with respect to the authorship and/or publication of this article.

\section{Funding}

The authors received no financial support for the research and/or authorship of this article.

\section{REFERENCES}

1. Ziff M. The rheumatoid nodule. Arthritis Rheum 1990;33:761-7.

2. Cunnane G, Warnock M, Fye KH, Daikh DI. Accelerated nodulosis and vasculitis following etanercept therapy for rheumatoid arthritis. Arthritis Rheum 2002;47:445-9.

3. Kerstens PJ, Boerbooms AM, Jeurissen ME, Fast JH, Assmann KJ, van de Putte LB. Accelerated nodulosis during low dose methotrexate therapy for rheumatoid arthritis. An analysis of ten cases. J Rheumatol 1992;19:867-71.

4. Kerstens PJ, Boerbooms AM, Jeurissen ME, Fast JH, Assmann KJ, van de Putte LB. Accelerated nodulosis during low dose methotrexate therapy for rheumatoid arthritis. An analysis of ten cases. J Rheumatol 1992;19:867-71.

5. Langevitz P, Maguire L, Urowitz M. Accelerated nodulosis during azathioprine therapy. Arthritis Rheum 1991;34:123-4.

6. Sayah A, English JC. Rheumatoid arthritis: a review of the cutaneous manifestations. J Am Acad Dermatol 2005;53:191-209.

7. Yamamoto T. Cutaneous manifestations associated with rheumatoid arthritis. Rheumatol Int 2009;29:979-88.

8. Ahmed SS, Arnett FC, Smith CA, Ahn C, Reveille JD. The HLA-DRB1*0401 allele and the development of methotrexate-induced accelerated rheumatoid nodulosis: a follow-up study of 79 Caucasian patients with rheumatoid arthritis. Medicine (Baltimore)
2001;80:271-8

9. Filosa G, Salaffi F, Bugatti L. Accelerated nodulosis during methotrexate therapy for refractory rheumatoid arthritis. A case report. Adv Exp Med Biol 1999;455:521-4.

10. Motegi S, Ishikawa O. Methotrexate-induced accelerated nodulosis in a patient with rheumatoid arthritis and scleroderma. Acta Derm Venereol 2014;94:357-8.

11. Merrill JT, Shen C, Schreibman D, Coffey D, Zakharenko O, Fisher R, et al. Adenosine A1 receptor promotion of multinucleated giant cell formation by human monocytes: a mechanism for methotrexateinduced nodulosis in rheumatoid arthritis. Arthritis Rheum 1997;40:1308-15.

12. Wikaningrum R, Highton J, Parker A, Coleman M, Hessian PA, Roberts-Thompson PJ, et al. Pathogenic mechanisms in the rheumatoid nodule: comparison of proinflammatory cytokine production and cell adhesion molecule expression in rheumatoid nodules and synovial membranes from the same patient. Arthritis Rheum 1998;41:1783-97.

13. Mackley CL, Ostrov BE, Ioffreda MD. Accelerated cutaneous nodulosis during infliximab therapy in a patient with rheumatoid arthritis. J Clin Rheumatol 2004;10:336-8.

14. Bautista BB, Boyce EG, Schumacher HR. Effects of Second-line Drugs on the Progression or Regression of Rheumatoid Nodules. J Clin Rheumatol 1995;1:213-8.

15. Combe B, Guttierrez M, Anaya JM, Sany J. Possible efficacy of hydroxychloroquine on accelerated nodulosis during methotrexate therapy for rheumatoid arthritis. J Rheumatol 1993;20:755-6.

16. Dash S, Seibold JR, Tiku ML. Successful treatment of methotrexate induced nodulosis with D-penicillamine. J Rheumatol 1999;26:1396-9.

17. Abraham Z, Rozenbaum M, Rosner I. Colchicine therapy for low-dose-methotrexate-induced accelerated nodulosis in a rheumatoid arthritis patient. J Dermatol 1999;26:691-4.

18. Chatham WW. Methotrexate associated rheumatoid nodulosis: improvement with addition of sulfasalazine. Arthritis Rheum 1992;35(Suppl):S148.

19. De Stefano R, Frati E, Nargi F, Menza L. Efficacy of rituximab on pulmonary nodulosis occurring or increasing in patients with rheumatoid arthritis during anti-TNF- $\alpha$ therapy. Clin Exp Rheumatol 2011:29:752-3.

20. Andres M, Vela P, Romera C. Marked improvement of lung rheumatoid nodules after treatment with tocilizumab. Rheumatology (Oxford) 2012;51:1132-4.

21. Sautner J, Rintelen B, Leeb BF. Rituximab as effective treatment in a case of severe subcutaneous nodulosis in rheumatoid arthritis. Rheumatology (Oxford) 2013;52:1535-7. 